African Journal of Biomedical Research, Vol. 9 (2006); 229 - 233

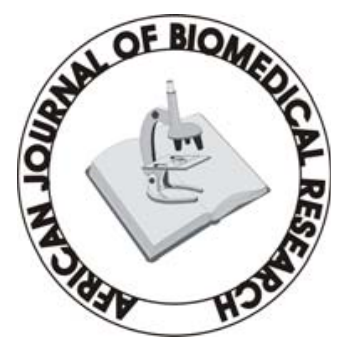

Full-text available at http://www.ajbrui.com http://www.bioline.br/md http://www.ajol.com

Received:

April 2006

Accepted (Revised):

July 2006

Published

September 2006
Full Length Research Article

\section{Anti-Inflammatory and Anti-nociceptive Effects of Ethanolic Extract of Setaria megaphylla Leaves in Rodents}

\author{
${ }^{* 1}$ Okokon, Jude E. ${ }^{2}$ Antia, Bassey S. ${ }^{2}$ Ita, Basil N \\ ${ }^{1}$ Dept. of Pharmacology \& Toxicology, \\ Faculty of Pharmacy University of Uyo, \\ Uyo - Nigeria \\ 2 Dept of Chemistry, University of Uyo, \\ Uyo - Nigeria
}

\section{ABSTRACT}

The ethanolic leaf extract of Setaria megaphylla $(100-300 \mathrm{mg} / \mathrm{kg})$ was investigated for pharmacological properties against egg white albumin - induced inflammation, Chemical as well as thermal- induced pain. The extract demonstrated a dose - dependent anti- inflammatory and antinociceptive activities. These activities were comparable to that of ASA $(100 \mathrm{mg} / \mathrm{kg})$. The leaf extract possess anti inflammatory and analgesic properties, which can be exploited in health care

(Afr. J. Biomed. Res. 9: 229 - 233)

Keywords: Setaria megaphylla, anti inflammatory, analgesic.

*Address for Correspondence (e-mail): judeefiom@yahoo.com, Tel (+234)802-345-3678

Abstracted by:

African Index Medicus (WHO), CAB Abstracts, Index Copernicus, Global Health Abstracts, Asian Science Index, Index Veterinarius, Bioline International , African Journals online 


\section{INTRODUCTION}

Setaria megaphylla (steud) Dur schinz (familyPoaceae) also called broad leafed brittle grass is a very tall, robust, tufted, perennial grass used mainly as pasture. It occurs in tropical and subtropical areas of Africa, America and India where there is high rainfall (Van oudtshoorn, 1999, Lowe, 1989). The plant is used traditionally by the Ibibios in Akwa Ibom State of Nigeria, in the treatment of various ailments such as hemorrhoids, Urtheritis and diabetes. The plant has been reported to possess antiplasmodial activity in vitro (Clarkson et al, 2004) as well as antidiabetic activity (Okokon and Antia, 2005). The leaves have been reported by Okokon and Antia (2005) to contain flavonoids, terpenes, saponins, tannins, anthraquinones, cardiac glycosides, while alkaloids are reported to be absent. However, no anti-inflammatory and analgesic effect of the leaves has been reported earlier in the literature. The present study, therefore, was to establish if the leaves of $S$. megaphyglla have any analgesic/ant-inflammatory effect especially because of its ethnomedical uses in the treatment of inflammatory cases

\section{MATERIALS AND METHODS}

\section{Plant materials}

Fresh leaves of Setaria megaphylla were collected in November, 2004 at Anwa forest in Uruan, Akwa Ibom State, Nigeria . The plant was identified and authenticated by Dr. Margaret Bassey, a taxonomist in the Department of Botany, University of Uyo, Uyo. Nigeria. Hebarium specimen was deposited at Faculty of Pharmacy Hebarium with voucher no. FPHUU 221. The fresh leaves $(2 \mathrm{~kg})$ of the plant were dried on laboratory table for 2 weeks and reduced to powder. The powder $100 \mathrm{~g}$ was macerated in $95 \%$ ethanol $(300 \mathrm{ml})$ for 72 hours. The liquid filtrate obtained was concentrated in vacuo at $40^{\circ} \mathrm{C}$. The yield was $2.08 \%$ $\mathrm{w} / \mathrm{w}$. The extract was stored in a refrigerator at $4^{\circ} \mathrm{C}$ until used for experiment reported in this study.

\section{Animals:}

Albino swiss mice (21-28g) of either sex were obtained from the University of Uyo animal house.
They were maintained on standard animal pellets and water ad libitum. Permission and approval for animal studies were obtained from the College of Health Sciences Animal Ethics committee, University of Uyo.

\section{Anti-Inflammatory Test}

The test was carried out using a phlogistic agent - induced mouse hind paw oedema as a model of acute inflammation (Winter et al, 1963) The phlogistic agent employed in this study was fresh egg-albumin (Akah and Nwambie, 1994). Adult Swiss mice of either sex (21 - 28g) were used after a $12 \mathrm{~h}$ fast. Animals were deprived of water only during the experiment. Inflammation of the hind paw was induced by injection of $0.1 \mathrm{ml}$ of fresh egg white into the subplantar surface of the right hind paw of the mice. Paw diameters were measured immediately before the administration of the phlogistic agent and 3 hours thereafter. For routine drug testing, the increase in paw diameter 3 hours after administration of the phlogistic agent was adopted as the parameter for measuring inflammation (Winter et al, 1962). Thus (inflammation) was assessed as the difference between zero time paw diameter and that 3 hours after administration of phlogistic agent (Hess and Milonig, 1972). The extract $(100,200$ and 300 $\mathrm{mg} / \mathrm{kg}$ ) were administered i.p 1 hour before inducing inflammation. Control mice received equivalent amount of normal saline and the reference group administered Acetic salicylic acid (ASA) $100 \mathrm{mg} / \mathrm{kg}$. Average oedema $\left(C_{t}-C_{0}\right)$ and percent inhibition of oedema were calculated for each dose (Oriowo,1982; Akah and Njike, 1990).

\section{Acetic acid - induced writhing in mice}

The analgesic activity of ethanolic leaf extract of Setaria megaphylla was measured against acetic acid induced writhmic movements in mice (Collier, 1968; Santos et al, 1994), consisting of the contraction of abdominal muscle together with the stretching of hind limbs. The extract at doses of 100, 200 and $300 \mathrm{mg} / \mathrm{kg}$ and ASA $100 \mathrm{mg} / \mathrm{kg}$ and normal saline $5 \mathrm{ml} / \mathrm{kg}$ were administered intraperitoneally to the respective groups $(\mathrm{n}=5)$ of the 18hours fasted mice. Thirty minutes later, $0.5 \mathrm{ml}$ of $2 \% \mathrm{v} / \mathrm{v}$ acetic acid solution was given to each animal intraperitioneally. 
The animals were then placed in separate plastic cages and closely observed at 10minutes interval for 50minutes. The number of writhes for each animal was counted. Percent inhibition of pain for each group was calculated by comparing the total writhetic number of writhes in the group over the 50 minutes period with the number of writhes in the control group over the same time period. Data were calculated according to the following formula.

Where,

$$
\% \text { Inhibition }=\frac{W t-W c}{W c} \times 100
$$

$W t=$ Mean number of writhes for the test group

$W c=$ Mean number of writhes for the control group

\section{Thermally - induced pain in mice}

The effect of extract on hot plate - induced pain was investigated in adult mice. The hot plate test was used to measure response latencies according to the method of Vaz et al, $(1996,1997)$. The animals were divided into 5 groups of 5 mice each. Group 1 mice served as the control and received only saline. Groups 2, 3 and 4 were pre- treated with 100, 200 and $300 \mathrm{mg} / \mathrm{kg} S$. megaphylla extract i.p respectively, 30min prior to the placement on the hot plate, while group 5 animals received $100 \mathrm{mg} / \mathrm{kg}$ of ASA by i.p route. The hot plate was set at $45 \pm 1^{\circ} \mathrm{C}$ and animals were placed into a glass beaker of $50 \mathrm{~cm}$ diameter on the heated surface and the time(s) between placement and shaking or licking of the paws or jumping was recorded as the index of response latency.

\section{Statistical analysis}

Data are expressed as mean \pm SEM for $n$ numbers of experiment. Statistical comparisons and significance levels were analyzed with student's $t$ - test. A 'p' value less than 0.05 was considered as significant

\section{RESULTS}

\section{Fresh Egg Induced Inflammation in Mice}

The extract showed significant $(\mathrm{P}<0.05)$ antiinflammatory activity against acute inflammation. (Table 1). It suppressed in a dose related manner the increase in the mice paw edema caused by egg albumin. The inhibition by the extract was maximal after 3hours of administration of phlogistic
agent.The effect which was significant when compared to control was comparable to that of the standard drug,ASA.

\section{Acetic Acid - Induced Writhing In Mice}

The extract (100 - 300mglkg) dose - dependently reduced acetic acid induced abdominal constructions and stretching of hind limbs. The reduction was significant $(\mathrm{P}<0.05)$ (Table 2) when compared to control. The analgesic effect was comparable to that of ASA.

Table 1:

Effect of Setaria megaphylla on fresh egg albumin induced inflammation in rats.

\begin{tabular}{llll}
\hline Treatment & $\begin{array}{c}\text { Dose } \\
\mathbf{m g} / \mathbf{k g}\end{array}$ & $\begin{array}{c}\text { Paw Diameter } \\
\mathbf{c m}\end{array}$ & $\begin{array}{c}\text { Inhibition } \\
\mathbf{\%}\end{array}$ \\
\hline Control & & $0.69 \pm 0.03$ & - \\
\hline $\begin{array}{l}\text { S. megaphylla } \\
\text { extract }\end{array}$ & 100 & $0.29 \pm 0.02^{*}$ & 57.97 \\
\cline { 2 - 4 } & 200 & $0.28 \pm 0.03^{*}$ & 59.42 \\
\cline { 2 - 4 } & 300 & $0.27 \pm 0.03^{*}$ & 60.86 \\
\hline ASA & 100 & $0.26 \pm 0.01^{*}$ & 62.31 \\
\hline
\end{tabular}

Results are expressed as mean \pm SEM $(n=5) * P<0.05$ significantly different from control.

Table 2 .

Analgesic activity of ethanolic leaf extract of Setaria megaphylla on acetic acid induced writhing in mice.

\begin{tabular}{|c|c|c|c|}
\hline Treatment & $\begin{array}{l}\text { Dose } \\
\mathrm{mg} / \mathrm{kg}\end{array}$ & $\begin{array}{l}\text { No. of } \\
\text { Writing }\end{array}$ & $\begin{array}{l}\text { Percent activity } \\
\text { against acetic acid } \\
\text { induced pain }\end{array}$ \\
\hline Control & & $\begin{array}{l}237.3 \\
\pm 18.50\end{array}$ & \\
\hline \multirow[t]{3}{*}{$\begin{array}{l}\text { S. megaphylla } \\
\text { extract }\end{array}$} & 100 & $\begin{array}{l}161.7 \pm \\
5.06^{*}\end{array}$ & 31.85 \\
\hline & 200 & $\begin{array}{l}119.4 \pm \\
3.18^{*}\end{array}$ & 49.96 \\
\hline & 300 & $\begin{array}{l}40.5 \pm \\
7.21 *\end{array}$ & 82.93 \\
\hline AS A & 100 & $\begin{array}{l}53.0 \pm \\
2.80 *\end{array}$ & 77.66 \\
\hline
\end{tabular}

Results are expressed as mean \pm S.D $(n=5) * P<0.05$ significantly different from control 


\section{Thermally- Induced Pain In Mice}

Administration of $S$. megaphylla extract (100 $300 \mathrm{mg} / \mathrm{kg}$ i.p) elicited a dose - dependent increase in the latency response in the hot plate test. These increases in latency responses (analgesic effect) were statistically significant $(\mathrm{P}<0.05)$ (Fig. 1), when compared to control.

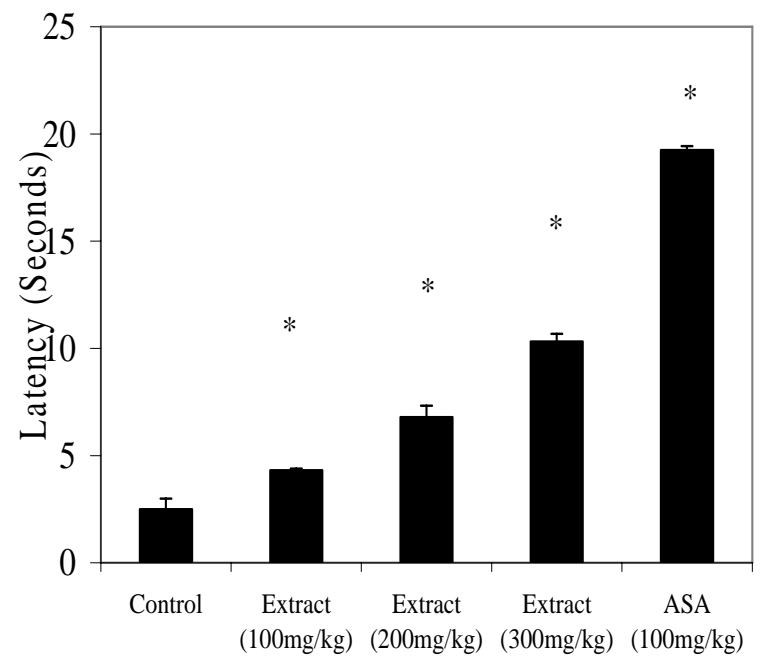

Fig. 1.

Effect of S. megaphylla on thermally induced pain in rats. ${ }^{*} \mathrm{P}<0.05$ significantly different from control

\section{DISCUSSION}

The ethanolic leaf extract of $S$. megaphylla significantly reduced edema of the mouse hind paw induced by fresh egg albumins. This dose dependent action; was comparable to that of a acetylsalicylic acid, a cyclo-oxygenase inhibitor (Singh et al, 1996). Flavonoids which are some of the constituents of the extract have anti inflammatory property (Trease and Evans, 1989; Parmer and Gosh, 1978), Edema is attributed to the release of histamine, 5-HT, Kinins and prostaglandins (Vane and Booting, 1987, Larsen and Henson, 1983) and the anti inflammatory action of this extract may be due to the inhibition of the release of the above mentioned autocoids.

The leaf extract was also found to possess significant $(\mathrm{P}<0.05)$ dose and time - dependent analgesic activity against chemical and thermal - induced pains. Acetic acid causes inflammatory pain by inducing capillary permeability (AmicoRoxas et al, 1984) while hot plate-induced pain indicates narcotic involvement (Turner,1965; Besra et al, 1966). The ability of the extract to show significant effect in these two types of pain induction suggest that its analgesic effect may in part be related to its anti inflammatory and narcotic properties.

Therefore, the result obtained in this study shows that $S$. megaphylla possess anti-inflammatory and analgesic properties which are probably mediated via inhibition of various autocoids formation and release. Further studies are needed to elucidate the exact mechanism by which $S$. megaphylla inhibits inflammation and pains

\section{Acknowledgement}

The authors are grateful to Ms. Sifon Akpan of Dept of Pharmacology and Toxicology, University of Uyo, Uyo for her assistance.

\section{REFERENCES}

Akah, P. A. and Njike H. A. (1990). Some pharmacological effects of rhizome acqueous extract of Achomanes diformes. Fitoterapia 60:368-370

Akah, P.A., Nwambie A; (1994) Evaluation of Nigerian traditional Medicines: 1 Plants used for rheumatic (inflammatory) disorders. Journal of Ethnopharmacology 42, 179 - 182

Amico - Roxas, M., Caruso, A; Trombadore, S; Safo R; Scapagnini, U. (1984). Gangliosides antinociceptive effects in rodents. Archieves Internationals de pharmacodynamic et de Therapie. 272, 103- 117.

Besra, S.E; Sharma, R.M; Gomes, A. (1996). Anti-inflammatory effect of Petroleum ether leaves extract of Litchi chinensis Gaertn (Sapindaceae). Journal of Ethnopharmacology. 54:1-6

Clarkson C; Maharay V.J; Crouch N. R; Grace O. M; Pillay P. Matsabisa M. G; Bhagwandin N; Smith P.J. and Folb P.I. (2004): In vitro antiplasmodial activity of Medicinal plants native to or naturalized in South Africa. J. Ethnopharm. 92 (2/3) 177-191.

Collier, H. O. J. Dinner, L. C. Schneider, C. (1968): The abdominal constriction response and its 
suppression by analgesic drugs in the mouse. Br. J. Pharmacol. Chemothe. 32:295-320

Hess, SM and Milonig, RC (1972). In L.H. Lepow and P.S. Ward (Eds) Inflammation, Mechanism and Control. Academic Press. New York.

Larsen G.L. Henson, P. M. (1983) Mediators of Inflammation. Ann. Rev. Immunol. 1:335-359.

Lowe J. (1989). The Flora of Nigeria Grasses. $2^{\text {nd }}$ edition. Ibadan University Press. Ibadan, Nigeria.

Okokon J. E, Antia B. S. (2005) Hypoglycaemic and antidiabetic activity of ethanolic leaf extract of Setaria megaphylla on normal and alloxan diabetic rats. Journal of Natural Remedy (In Press).

Oriowo, MA. (1982). Anti inflammatory activity of piperonyl -4- acrylic isobutyl amide, an extractive from Zanthoxylum zamthoxyloids. Planta Medica. 2:54-56.

Parmer, N. S, Ghosh M. N. (1978) Anti inflammatory activity of gossypin a bioflavonoid isolated from Hibiscus vitifolicus Linn. Ind. J. Pharmacol.10:277-293.

Santos, A.R. S; Cechinel Filho, V., Niero, R; Viana, A.M., Moreno F. N; Campos, M. M; Yunes R. A; Calixto, J. B. (1994) Analgesic effect of callus culture from selected species of Phyllanthus. Journal of Pharmacy and Pharmacology. 46:755-759.

Singh, S., Majumdar D. K, Rehan H. M. S (1996) Evaluation of anti inflammatory potential of fixed oil of Ocimun sanctum (Holy basil) and its possible mechanism of action. Journal of Ethnopharmacology 54, 19-26.

Trease GE, Evans W. C., (1989) Pharamacognosy $13^{\text {th }}$ Ed. Bailliere tindall, London. Pp.683-684.

Turner, R. A (1965). Screening Methods in Pharmacology, Vol. I. Academic Press. New York. 85-106.

Van Oudtshoorn F.P. (1999) Guide to Grasses of South Africa. Briza Publications. Cape town.

Vane T. Booting R. (1987) Inflammation and Mechanism of action of anti inflammatory drugs. FASSEB J. 1:89-96.

Vaz, Z. R; Cechinel V; Yunes, R.A; Calixto, J. B; (1996). Antinociceptive action of $2-(-4$ bromo benzoyl -3-methyl -4-6-dimethoxy benzofuran, a novel xanthoxyline derivative of chemical and thermal models of nociception in mice. Journal of pharmacology and Experimental therapeutics. 278(1):304-312.

Vaz, Z. R; Mata L. V; Calixto, J. B (1997). Analgesic effect of the herbal medicine catuama in thermal and chemical models of nociception in mice. Phytotherapy Research. 11,101-106.

Winter, CA, Risley, E.A; Nuss G.W. (1962). Carragenin induced oedema in hind paw of the rats as an assay of anti-inflammatory drugs. Proceedings of the Society for Experimental Biology and Medicine .111:544-547.

Winter E.A, Risley, EA, Nuss GV. (1963) Anti inflammatory and antipyretic activities of indomethacin. J. Pharm. Exp. Ther.141:369-376. 